\title{
THE DISTRIBUTION OF WAGE-EARNER'S LIFE INSURANCE
}

\author{
Edwin W. Patterson*
}

The distribution of wage-earner's life insurance is the process of establishing and maintaining the legal relations of insurer and insured between the insurance carrier and the persons who need or desire such insurance. Roughly speaking, it is the selling of insurance. Analysis of the various distribution schemes which have thus far been employed indicates that the distribution process may significantly be subdivided as follows: $x$. Solicitation and persuasion of the prospect. 2. Information service, that is, the giving of reliable information as to the terms of the contract and impartial guidance as to its adaptability to the needs of the prospect. 3. Underwriting service, including the selection of the risk (with or without medical examination), the taking of the application, the delivery of the policy, and the collection of the first premium. 4. Collection of subsequent premiums. 5. Solicitation and persuasion of the insured to continue premium payments. With due apologies to those readers who may, not unnaturally, have been misled into believing that the title of this article referred to the statistical distribution of policyholders among income groups, occupation groups, age groups, population areas, etc., it may be pointed out that an analogy is here suggested between the distribution of insurance and the distribution of ordinary merchandise. Whereas the two are scarcely comparable with respect to the production ${ }^{1}$ process, i.e., the process of economically producing a sound article, with respect to the distribution process one finds similar problems of economy and efficiency which are far from being satisfactorily solved. The present essay is intended to survey briefly some of the distribution problems of wage-earner's life insurance.

Since the purpose is to analyze these problems in terms which are not confined to any single institution (such as industrial life insurance, savings bank life insurance, government insurance) it is necessary to define what is meant by wage-earner's life

* A.B., I909, LL.B., I9II, University of Missouri; S.J.D., Harvard, I920. Associate Professor and Professor of Law at Columbia University since 1922. Adjunct Professor of Law, University of Texas, 1915-I7; Assistant Professor and Professor of Law, University of Colorado, I917-I9; Professor of Law, State University of Iowa, x920-22. Author of The Instrance Commissioner in the United States (I927); Cases and Materials on Insurance (1932); Essentials of Insurance Law (1935).

1 The term "production" is used by life insurance companies in a wholly different sense; that is, to mean the selling of insurance, especially of new insurance. 
insurance. Historically, insurance means a scheme of risk-distribution whereby persons exposed to similar risks receive payments, in case of loss, from a fund derived solely from contributions made by the persons so exposed. In other words, insurance is here taken to mean a completely self-sustaining, unsubsidized plan of risk-distribution. To confuse profit-making with economic individualism is so easy that one may be pardoned for pointing out that life insurance is, in the United States today, typically not a profit-making business, but that it is individualistic in the sense of being self-sustaining. Insistence upon this definition will serve to indicate clearly when proposals for government insurance cease to be insurance and cross the line from individualism to paternalism, philanthropy or charity. ${ }^{2}$

By life insurance is meant any contract to pay a named or ascertainable sum upon the death of a person. Here the possibilities include term insurance in its various forms, whole life insurance, limited payment life insurance, and endowment life insurance, but not pure endowment contracts nor annuity contracts. Policies providing for accidental death benefits may be included, but weekly indemnity benefits, whether payable only in case of accident, or in case of disability arising otherwise, do not fall strictly within the scope of the topic, although closely related institutionally.

The term "wage-earner" obviously refers to those persons falling in the lowest income group. This may be taken to include, roughly speaking, all of those whose annual income is below $\$ 2,000$. These persons, with their immediate families, constitute fully seventy per cent of the population of the United States. If one excludes farmers and others who are technically not wage-earners but entrepreneurs (a distinction of doubtful significance for the present purpose) and if one excludes further those persons (and their dependents) who are not engaged in industrial occupations, the percentage falls to about one-half. ${ }^{3}$ Exact figures are not, at this stage, important. Obviously the problem is of sufficient magnitude to justify the thorough study which the editor of this journal has sought to give it. It is important to understand what the problem involves.

The question at issue might be limited to the most economical and effective method of distributing insurance on the lives of wage-earners. This limitation would bring out the social objectives of the study, which are presumably to determine how the economic losses caused, to dependents and others, by the death of the wageearner, can best be covered by insurance. Yet this restriction of the problem would exclude consideration of the large proportion of industrial insurance which is written on the lives of children and of others who are dependents rather than wage-earners. These policies, it is submitted, represent doubtful social values; yet they are paid for

\footnotetext{
${ }^{2}$ Tested by this definition many of the proposals for unemployment insurance are not pure insurance, but are combinations of insurance and unemployment relief. This is not meant to depreciate their social value, but it does indicate the direction of social change.

${ }^{3}$ Dr. Maurice Taylor, to whom we are indebted for much valuable information and analysis of the problem, estimates the potential purchasers of industrial life insurance at 62,000,000 in 1930. Tarzon, The Social Cost of Industrial Insurance (1933) $62 \mathrm{n}$.
} 
out of the wage-earner's income and presumably are what he (or she) wants. They surely cannot be ignored in an analysis of insurance schemes functioning on the presupposition of individualism. Individual incentives are unfortunately not identical with social objectives. Here the problem bifurcates: $x$. What is the most economical and effective method of giving the wage-earner the life insurance he wants? 2. What is the most economical and effective method of getting him to take what he ought to want?

The position here taken that the wage-earner's wants and his needs diverge to a significant extent may be open to question. In the first place it may be argued that such a conclusion implies a Pharisaical or paternalistic attitude toward the wageearner, who needs guidance from the more enlightened members of the community (including especially the writer). But this objection is a specious one. Since insurance has long been subject to regulation and control by the state, and since the state can act, legitimately, only for social objectives, a proposal that the state do something, or refrain from doing something, which will promote the social objectives of wageearner's life insurance is no more paternalistic or socialistic than is any other proposal for state action (or inaction). Legislation affecting insurance of salaried workers and of those in the higher income brackets has likewise been aimed at, and' can be justified only by, the attainment of social objectives. Even in the classical political economy of Adam Smith, the entrepreneur is not an end in himself but merely a means to satisfy the economic wants of society. 'This thesis is expanded in Ihering's analysis of the legal order in terms of social levers, coercion and reward. It is true that, with relief rolls growing and income taxes mounting, the more prosperous portions of the community are moved by incentives of self-interest to make the wageearner thrifty and self-sustaining, but it is by no means impossible for enlightened self-interest to further the social good.

A more serious objection to the position taken above is that the inferences, from which it is concluded that wage-earners' wants differ from their needs, are based upon the experience of industrial insurance carriers, and may therefore merely represent defects in their methods of distribution. Three factors of industrial experience stand out: I. The large proportion of policies taken on the lives of children. About thirty-seven per cent of the industrial policy-holders in 1930 were under fifteen years of age, and about twenty-seven per cent were under ten. ${ }^{4}$ 2. The large proportion of housewives whose lives are insured, ${ }^{5}$ as well as those who procure policies on the lives of others. ${ }^{6}$ 3. The extent to which funeral expenses afford the chief incentive to the procurement of the insurance, and absorb the greater part of the proceeds. ${ }^{\top}$ From these facts one may conjecture the incentives which lead to the procurement and maintenance of this insurance. Among them, it would seem, are fear of a pauper burial, love of a fine funeral, and an innocent desire to gamble a little on the

4Id. at 56.

II. at 59.
${ }^{8}$ See Id. at $4 x$.

'Ibid. 
lives of the young. These are quite normal human motives, but they do not promote the social objective of protecting the wage-earner's dependents, any more than does the large amount of insurance written on the lives of housewives. ${ }^{8}$ To pay for insurance on the lives of dependents is not the most prudent use of the wage-earner's limited funds. Individual incentives do not parallel social objectives.

Any proposal for an effective and widespread distribution of wage-earner's life insurance must take account of these facts. Five different methods of distributing wage-earner's life insurance have thus far been tried: $r$. Industrial life insurance sold through paid solicitors. 2. Fraternal insurance sold through lodges, sometimes with payment of compensation to solicitors. 3. Government insurance sold through postoffices (England and Japan). 4. Savings bank life insurance (Massachusetts). 5. Group insurance sold through employers. ${ }^{9}$ It is not assumed that these five plans are designed to reach the same persons, nor that any one method of distribution would be most effective for all wage-earners.

In the United States industrial life insurance is the only one which has come near blanketing its field. In terms of proportion of insured persons to the possible total of policyholders it has been successful, and this success has been maintained relatively better than in the case of ordinary life insurance, during the trying depression years. As a mere feat of sales organization and salesmanship the amazing growth of this business during the past thirty years excites admiration. Yet the price of success has been appalling. The cost of solicitation and collection (including supervisors' salaries), despite improved efficiency in methods ${ }^{\mathbf{1 0}}$ and despite the absence of any incentive to make profits, ${ }^{11}$ continues to absorb an inordinate proportion of the premium income. ${ }^{12}$ In estimating the cost, one must not overlook the restricted non-forfeiture values of industrial policies. ${ }^{13}$ Moreover, the industrial insurance

${ }^{8}$ Of course the death of the housewife causes economic loss, in funeral expenses and in the loss of her services, hence this insurance is not valueless.

${ }^{\circ}$ A sixth method, group insurance sold through labor unions, is described in the article by Mr. Hedges in this issue, Labor's Interest in Group Insurance, infra, p. 94 .

10 The percentage of premium income spent on commissions and salaries by companies doing business in New York decreased from 29.6 in 1921 to 19.6 in 1931 . (TAxLon, op. cit. supra note 3, 175). In Massachusetts a comparable percentage decreased from 30.99 in 1924 to 22.71 in 1933 . (CASNEn, MAsSachusetts Savings Bank Life Insurance, I9.)

II The three largest companies, which do about 75 per cent of the total industrial business (TAYLor, cp. cit. supra note 3,420 ) are mutual companies. Of course, the manager's incentive to increase his own compensation is not to be overlooked.

${ }^{2}$ Inordinate when compared with the expense ratio of ordinary life insurance, which decreased from I4.I to 12.8 (cf. TAYLOR, loc. cit. supra note 10) or when compared with that of Massachusctts Savings Bank life insurance, which was 6.10 per cent in 1924 and 5 per cent in 1933 (Casner, loc. cit, sitpra note I0). Of course the higher rate of mortality among industrial policyholders partly accounts for the higher premiums (Maclean, Life Insurance (2d ed. 1932) 358).

${ }^{23}$ Non-forfeiture benefits are those accruing to the policyholder when the insurance for the face amount of the policy terminates due to non-payment of premiums. These benefits are: 1 . Extended term insurance for the face amount, the term of which is based upon the amount of the premiums paid. 2. Paid-up insurance, unlimited as to term but reduced in amount. 3. Cash-surrender value. As a general rule industrial policies provide for the first two in case of cessation of premium payments after the policy has been in force three years, and for cash-surrender value only after ten ycars. (TAYzor, op. cit. supra 88, 9I.) In ordinary life policies (excepting term) either of the three benefits is payable after two or three years. (MACLEAN, op. cit. supra note I2, 150). 
organization seems better adapted to get the policy sold than to keep it in force. The striking lapse ratio in industrial insurance has long been a source of worry to company officials; it persists in spite of the pressure exerted upon the local solicitors. $^{14}$ Industrial life insurance has mounted, like the frog in the old arithmetic problem, by jumping upward three feet and sliding backward two. ${ }^{15}$

To examine fully the merits and demerits of industrial life insurance is beyond the scope of this article. The industrial companies have succeeded in persuading the industrial wage-earner to buy insurance. They have only partially succeeded in getting him to take the kind of insurance he needs most, or to take an amount of insurance even moderately proportionate to the needs of his dependents in case of his death. It is easy to conclude that this is due to faulty methods of distribution; but it seems equally due to the intractability of the prospect. The assumption that all men will act in accordance with enlightened self-interest is still only an assumption.

Fraternal insurance offers the possibility of reducing distribution costs by luring the prospect into the insurance trap through amateur solicitation, aided by social and lodge features. Yet the relative decline of fraternal insurance during the period when industrial insurance was growing rapidly, and also during the period when fraternal societies were required by law to promise no more than they could perform, indicates that its apparent success around the turn of the century was not based upon a distribution plan which should be emulated. The phenomenal growth of fraternal insurance during the last quarter of the nineteenth century was due more to unsound rates than to superior methods of distribution.

In England the distribution of life insurance in small amounts through local postoffices proved unsuccessful, and was abandoned after forty-three years. Here, as in the case of the languishing Belgian experiment, the failure to attain effective distribution seems due to lack of salesmanship. ${ }^{16}$ Although in Japan government life insurance, issued in small amounts through post-offices, has attained wide distribution, there seems no reason to believe that the wage-earning population of the United States would be induced to procure life insurance from post-offices even if it were made a government monopoly, as it is in Japan. ${ }^{17}$ The wage-earner can get along without life insurance better than he can get along without postage stamps. The postal savings banks, as agencies of distribution, could probably be adapted to

\footnotetext{
${ }^{14}$ By special compensation based upon the net weekly increase in the number of his policies in force, TANLOR, op. cit. stupra note 3 , 122 .

${ }^{15}$ Of the various ways of exhibiting the extent of lapse for non-payment of premiums in industrial insurance, the most striking is by presenting the ratio of lapsed policies to new policies written (in terms of the amounts of insurance). The best year for industrial insurance was 1920 , when the ratio was 4I.9 per cent. In 1930, it was 76.I per cent, and in 1932, III.4 per cent. (A smaller percentage is obtained if the total amount of insurance in force is taken as the base. See TAYLOR, op. cit. stipra note 3, I 40-1 42.) In Massachusetts, the corresponding figures for industrial insurance were 74.9 per cent (1930) and 107.45 per cent (1932) as compared with 1.20 per cent (1930) and 2.63 per cent (1932) for savings bank policyholders.

${ }^{20}$ See TAYIOR, op. cit. supra note 3, 321-323.

${ }^{17}$ Id. at 324 .
} 
accomplish all the objectives of a sound distribution plan except that of bringing in the customers. There is no reason to believe that they would be more successful in quantity distribution than have been the savings banks of Massachusetts. Moreover, the constitutional power of the federal government to engage in such a project seems highly questionable.

The Massachusetts Savings Bank Life Insurance plan has proved both sound and economical. The policies are issued by savings banks, but are buttressed by a guaranty fund which gives them the risk-spread of statewide operation. The policies are sold through clerks in savings banks and trust companies (not all of which issue policies) and to some extent through employers. No paid solicitors are employed, and the percentage of premium used for expenses is far less than in the case of industrial life insurance, or even of ordinary life. The rate of mortality is lower than that among industrial policyholders, partly because a medical examination is required. $^{18}$ The lapse ratio is extremely low, showing that the insurance stays sold. The wage-earner gets what he wants and, so far as one can tell, what he ought to have. In many respects it is an ideal plan. And yet the question remains open whether it will ever succeed in reaching a majority of those in the lower income levels of the wage-earning population. The average policy in force under the Massachusetts plan is around $\$ 900$, as compared with around $\$ 200$ for the average industrial policy. ${ }^{19}$ The total amount of insurance in force is only about one-tenth of the amount of industrial life insurance in force, and the total number of policies is correspondingly about two per cent of the total of industrial policies in Massachusetts. The savings bank plan has been in operation twenty-five years and during the past five years, at least, it has had good publicity. It has the influence of its illustrious author, Mr. Justice Brandeis. It has been endorsed both by employers' associations and by the American Federation of Labor and has the disinterested support of a voluntary association. Two instructors are employed to visit factories and explain the plan. Despite sound management and sound distribution methods it has failed to reach a very large segment of the wage-earning population. What more can be done?

The employer as an agency of distribution offers hopeful possibilities. The expense of solicitation and persuasion, and of premium collection, can be kept low. The employer has an interest in having the lives of his workers insured, and in giving them sound guidance as to the protection which they need. The personnel departments of large industrial concerns, already familiar with workmen's compensation insurance, can be adapted to give this guidance. Moreover, insurance through the employer may reach hazardous occupations and low income groups not reached by the Massachusetts plan. Yet it remains to be seen whether even the larger employers will voluntarily undertake this service for their employees, and whether the

${ }^{18}$ Only a small percentage of industrial policies are issued upon medical examination.

${ }^{10}$ Unfortunately, no figures are available, in either case, as to the average amount on each life insured; but it seems a fair inference that industrial policyholders are in a lower income group. 
employees will coöperate. ${ }^{20}$ A statute requiring the employer to apply the check-off to life insurance premiums would be of doubtful constitutionality since, unlike workmen's compensation, the wage-earner's life insurance bears no necessary and direct relation to industrial risks.

The conclusion to be drawn from this sketchy analysis of distribution agencies may be that wage-earner's life insurance, as above defined, is socially necessary but economically impossible. Having ventured so far in the rôle of the critic, one may as well venture further in the rôle of the prophet. Industrial life insurance will continue as a going concern for some time to come. The managers of these enterprises are not oblivious to their social responsibilities; and yet they cannot, in the face of competition, make their insurance more effective to attain social objectives without the aid of the state. Gresham's law, or a principle corresponding to it, operates in the field of insurance much as it does in the field of currency. The history of insurance legislation shows that it has been most effective where it drives out bad insurance in order that good insurance can thrive. ${ }^{21}$ Here too, legislation could curb the excesses of salesmanship. For instance, a statutory prohibition of insurance on the lives of children under ten would enable the industrial carriers to concentrate upon satisfying the genuine needs of the wage-earner for life insurance. Again, the abolition of weekly premium collections ${ }^{22}$ would surely reduce the expense ratio. Yet an irreducible minimum of expense will remain, and industrial life insurance, like other economic institutions, must yield ground to a less wasteful institution, whenever an equally effective one appears. For this reason the extension of the Massachusetts savings banks plan should be encouraged in all states which have both an insurance department adequate to the task of supervision and savings banks able and willing to take on this work. Its extension to other states must be accompanied by active propaganda if even a moderate success is to be attained.

The legitimate extension of wage-earners' life insurance will, it is believed, eventually be limited by the amount which the wage-earning population will absorb without the excessive distribution costs and the terrific lapse ratios which now prevail in industrial insurance. That portion of the lower income group ${ }^{23}$ which can be persuaded to take a pitifully inadequate amount of insurance only at an excessive cost of persuading them to take it should be denied this luxury. They can better be given economic security in the same manner as those who cannot afford any insurance, namely, through a program of social relief. The distribution of wageearner's life insurance must be adjusted to this larger program, when it comes.

${ }^{\infty}$ A question too involved for discussion here. Group insurance has aroused labor opposition because it penalizes the employee who quits.

2 The writer has presented this thesis in the article Insurance Law and Regulation, 8 Encyc. Soc. Scr. (1932) ro6, ri2.

Such a statute could not impair the obligation of existing contracts; but in view of the high lapse ratio, a statute operating prospectively would in a few years eliminate most of the weekly premium contracts.

${ }^{23}$ E. g., the domestic servant group. 